\title{
変形能力を考慮した RC 部材のせん断設計法 A SHEAR DESIGN PROCEDURE FOR R/C MEMBERS WITH DUCTILITY
}

\author{
市之瀬敏勝* \\ Toshikatsu ICHINOSE
}

\begin{abstract}
A design procedure is presented to prevent the shear failure of reinforced concrete members after flexural yielding. The procedure is based on truss-strut model. The inclination of truss action is assumed to increase in hinging regions considering reduced aggregate interlocking. Effective compressive strength of concrete is assumed to degrade in hinging regions considering crossed shear cracks. The procedure is confirmed by existing experimental data.
\end{abstract}

Keywords : reinforced concrete; shear failure; ductility; truss; strut; hinge region

§1.はじめに

これまで，鉄筋コンクリート部材のせん断設計は，荒 川式・広沢式などの実験式によることが多かった。しか し, Nielsen ${ }^{1)}$, Thurlimann ${ }^{21}$, 称原 ${ }^{31}$, 南 ${ }^{4)}$, Collins ${ }^{5)}$ ら の提案により，2 次元的な応力度の釣合いを考慮したせ ん断設計への道が開けてきた。日本建築学会，「鉄筋コ ンクリート造建物の終局強度型耐震設計指針 (案) ・同 解説 $\rfloor^{6}$ ) 第 6 章に示されたせん断設計法 (以後, 指針案 と呼ぶ）は，これら既往の提案の延長線上に位置づけら れる。

指針案が既往の研究から取り入れた最も重要な点は, 部材のせん断強度をトラス機構とアーチ機構の足し合わ せとする，称原 ${ }^{3}$, 南4) の考え方である。

指針案は，降伏ヒンジを計画しない部材と計画する部 材 (以後, 非じん性部材, じん性部材と呼ぶ) とに分け て設計法を示している。非じん性部材の設計法は, 部材 のせん断強度を一様なトラス機構と対角線状のアーチ機 構の足し合わせとしており，称原・南の提案とほぼ同一 である。彼らの提案と異なるのは，次の 3 点である。

（1）主筋の降伏を無視することによって，曲げ設計と せん断設計を分離できるようにした。

（2） Thurlimann ${ }^{2}$ の提案に従って，トラス機構の圧 縮力の向きが材軸之交わる角度 $\phi$ を， $\phi \geqq 26.5^{\circ}$ でなけ ればならないものと仮定した。すなわち， $\cot \phi \leqq 2$

と仮定した。

（3） Nielsen" の提案に従って，コンクリートの有効 強度係数を次式で与えた。

$$
\nu_{0}=0.7-\frac{\sigma_{B}}{2000}
$$

$\sigma_{B}$ はコンクリート強度で単位は $\mathrm{kg} / \mathrm{cm}^{2}$

これらの修正についての議論・検討は，文献718) で既に 行っているので本報では省略する。

指針案のせん断設計法が既往のいずれの提案 ${ }^{(1) \sim(5)}$ も異なるのは，次の 2 点である。

1. 変形能力を考慮したこと………2 次元的な応力度の 釣合いを考慮したせん断設計法は,これまで主にヨー ロッパなど地震荷重の小さい地域で発達してきたため, 部材の強度のみが議論の対象となりがちであった。しか し指針案では，コンクリートの有効強度やトラス機構の 角度を必要変形能力に応じて制限することにより，曲げ 降伏後のせん断破壊が生じないようにしている。

2. 付着破壊の検討を行うこと………指針案のせん断設 計式は，荒川式・広沢式と比較して，大きめのせん断強 度を与える場合が多い。特にこの傾向は，せん断補強筋 量が多い場合に顕著である。しかしこの場合には，せん 断破壊が生じなくても，付着破壊により強度が損なわれ る危険性がある。また, 曲げ降伏後の付着破壊が生じる と, 塑性変形能力が著しく損なわれる。指針案のせん断 設計式を用いる場合は，付着破壊の検討を必ず行う必要 がある。

このうち,第 2 点については別の機会に譲るものとし, 本報は，第 1 点について論じる。すなわち，指針案で示 されたじん性部材のせん断設計法に関して仮定を明確に し，その仮定から何が導かれるのかを明らかにしたい。 


\section{§2. じん性部材のせん断設計式を導くための仮定}

\section{（1）コンクリートの有効強度}

危険断面から $1.5 \cdot D(D$ : 部材のせい) の領域をヒン ジ領域と呼ぶ。ヒンジ領域の幅は, 本来, 塑性ヒンジの 回転角や軸力, モーメント勾配などの関数で与えられる ベきであるが，ここでは簡単のため $1.5 \cdot D$ に固定する。

ヒンジ領域以外では，コンクリートの有効強度係数 は非じん性部材と同じく式 $(2)$ で与えられる $\left(\nu=\nu_{0}\right)$ ものとする。

部材が曲げ降伏以後の繰返し載荷を受ける場合, ヒン ジ領域内では，ひび割れが交差することによってコンク リートの有効強度 $\nu \cdot \sigma_{B}$ が低下する。そこで，ヒンジ領 域内での有効強度係数 $\nu$ を, 図一1すなわち次式 (3) のような塑性ヒンジの回転角 $R_{p}$ の関数と仮定する。

$$
\begin{aligned}
& \nu=\left(1-15 \cdot R_{p}\right) \nu_{0} \quad R_{p} \leqq 0.05 \mathrm{rad} \\
& =\nu_{0} / 4 \\
& R_{p}>0.05 \mathrm{rad}
\end{aligned}
$$

図一1の横軸には，指針案第 4 章の解説に略算値として 提示されている柱・梁・耐震壁の境界梁の設計用変形角 も示している。これによれば, 柱では $\nu=0.775 \nu_{0}$, 梁 では $0.7 \nu_{0}$ ，耐震壁の境界梁では $0.625 \nu_{0}$ となる。

式（3）の仮定の根拠は現在のところ希薄である ${ }^{i 11}$ 。 しかし, Vecchio ら ${ }^{91}$, 白井ら ${ }^{10)}$, 大久保ら ${ }^{11}$ 等, ひび 割れの入ったコンクリートの有効強度に関する研究も盛 んになりつつある。これらの研究の進展によっては, 式
（3）が再検討されることになろう。

（2） トラス機構の角度

両端ヒンジの部材の場合, せん断力は, 図一2(a)(b) のようなアーチ機構 (角度 $\theta$ ) とトラス機構（角度 $\phi_{h}$ ) で伝達されると考える。

図一2(b)、のうち, 部材端部の粗いハッチの領域では, トラス機構の角度の逆正接, $\cot \phi_{h}$ は, 次式の制限を 受けるものと仮定する。

$\cot \phi_{h} \leqq \lambda$

$\lambda$ は, 塑性ヒンジの回転角 $R_{\rho}$ の関数とし, 図一 3 で与 える。これは次のような理由による。

じん性部材では，主筋の降伏に伴ってヒンジ領域での 曲げせん断ひび割れが拡大する。塑性ヒンジの回転角が $R_{p}=0.02 \mathrm{rad}$ という状態を考えてみよう。多くの実験 のひび割れ状況を見ると，塑性ヒンジの変形は，高々 5 本程度の主要なひび割れによって生じているように見え る。とすれば，図一4のように，1本あだりの斜めひび 割れ（材軸となす角度は $45^{\circ}$ であるとする）によって $R_{p} / 5=0.004 \mathrm{rad}$ 程度の回転が生じることは十分に有り 得る。ひび割れ先端から材軸までの距離が仮に $500 \mathrm{~mm}$ であるとすれば，材軸でのひび割れ幅は，0.004 radX $500 \mathrm{~mm}=2 \mathrm{~mm}$ となる。Walraven ${ }^{15)}$ の実験・解析によ れば， $2 \mathrm{~mm}$ のひび割れ幅では骨材のかみ合い作用はほ とんど期待できない。すすなお，コンクリートの圧縮力

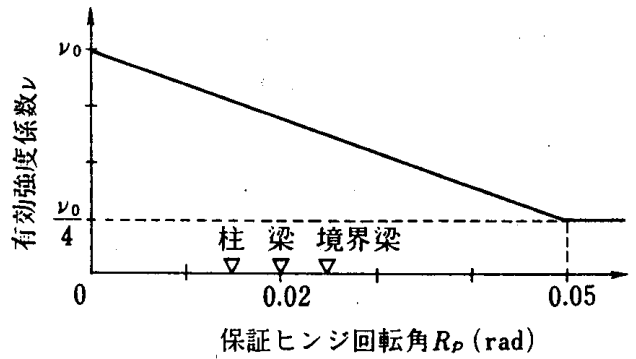

図一1 ヒンジ領域内での有効強度係数 上

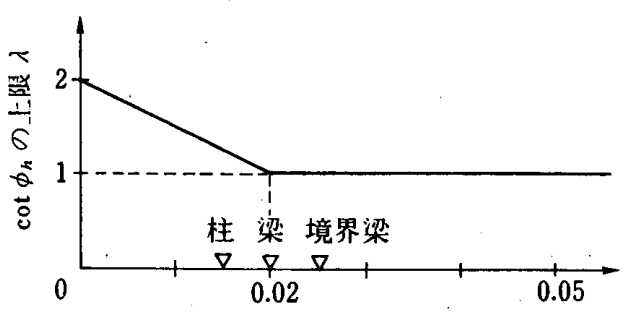

保証ヒンジ回転角 $R_{p}(\mathrm{rad})$

図一－上ラス機構の $\cot \phi$ の上限（ヒンジ領域内）
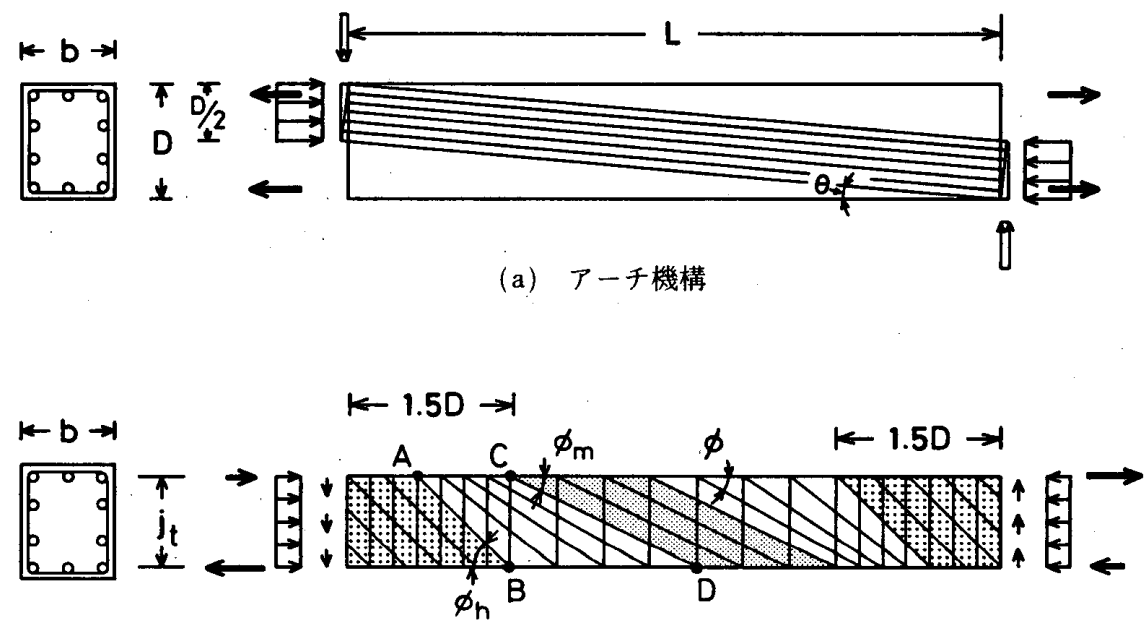

(b) トラス機構

図一2 両端ヒンジ部材でのせん断抵抗機構 


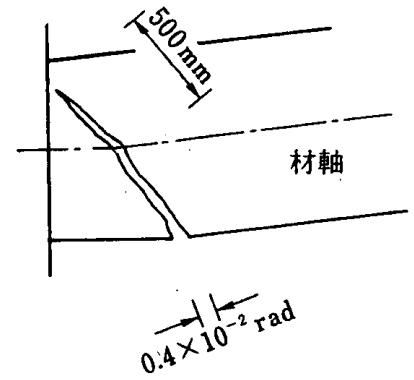

図一-4 トラス機構の角度を制限する理由ヒンジ領域でのひび割 れ

が斜めひび割れを横切って流れることはほとんど不可能 となり， $\phi_{h}=45^{\circ}$ のトラス機構のみが可能となる。現実 の部材において $\phi_{h}=45^{\circ}$ の状態がどの変形レベルで生じ るかは, 部材寸法, 配筋, 骨材等により異なるが, ここ では簡単のため, 前述の $R_{p}=0.02 \mathrm{rad}$ を目女をする。 すなわち，図一 3 のように， $R_{\boldsymbol{p}}>0.02 \mathrm{rad}$ の状態では $\cot \phi_{h}=1 \quad\left(\phi_{h}=45^{\circ}\right)$ のトラス機構のみを許容する。 $R_{p} \leqq 0.02 \mathrm{rad}$ の範囲では $\cot \phi_{h}$ の上限を 1 から 2 まで 徐々に緩める。

曲げせん断ひび割れの拡大に従って，トラス機構のみ ならず，ア一チ機構の応力伝達にも若干の支障を来す可 能性もある。しかし，ア一千機構の伝達領域は部材の圧 縮側であるので，斜めひび割れの拡大の影響は十分に小 さいものとみなす。

最後に, 図一2(b) のうち, 中央部の細かいハッチの 領域では，ヒンジの回転による斜めひび割れの拡大の影 響を受けないので，非じん性部材と同じく，

$$
\cot \phi_{m} \leqq 2 \cdots
$$

とする。ハッチの無い中間領域では $\phi$ は徐々に変化す ると考える。

\section{§3. 部材のせん断強度}

（1）トラス機構による負担せん断力

ヒンジ領域内でのせん断補強筋量を $p_{w h}$, ヒンジ領域 外でのせん断補強筋量を $p_{w m}$ とする。それぞれ $\sigma_{w h}$, $\sigma_{w m}$ の応力度を負担しているものとする。

トラス機構を図一2(b) の ABにおいて切断すると, 図一5(a) のようになる。そこで, トラス機構の負担せ ん断力 $V_{t}$ について次式を得る。

$$
V_{t}=b \cdot j_{t} \cdot p_{w h} \cdot \sigma_{w h} \cdot \cot \phi_{h}
$$

同じく, CD において切断することにより, 次式を得る。 $V_{t}=b \cdot j_{t} \cdot p_{w m} \cdot \sigma_{w m} \cdot \cot \phi_{m}$

式 $(6)(7)$ より,

$$
p_{w h} \cdot \sigma_{w h} \cdot \cot \phi_{h}=p_{w m} \cdot \sigma_{w m} \cdot \cot \phi_{m}
$$

が成立しなければならない证2 。

設計では，ヒンジ領域内でのせん断補強筋量をヒンジ 領域外より以上とするはずである $\left(p_{w h} \geqq p_{w m}\right)$ から，

$p_{w h} \cdot \sigma_{w h} \geqq p_{w m} \cdot \sigma_{w m} \cdot$

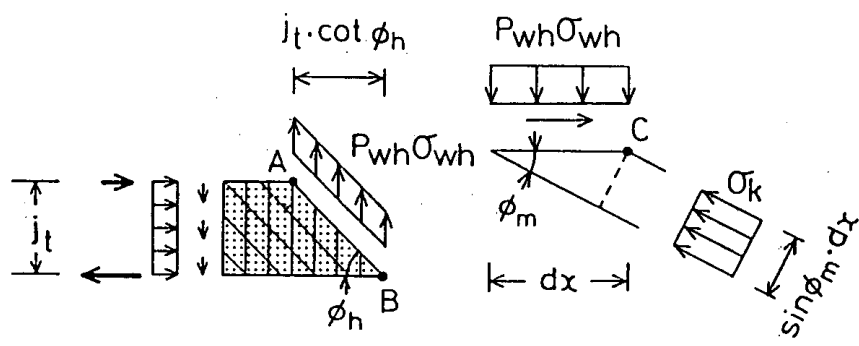

（a） トラス機構の切断

(b) C点近傍での釣合い

図一5 トラス機構の詳細

となる䄄。よって, 式 $(8)$ より， $\cot \phi_{h} \leqq \cot \phi_{m} \cdots$ となる。

なお，図一2(b) の $\mathrm{AB}$ と $\mathrm{CD}$ の間の任意の位置で切 断した場合にも，式 $(6)(7)$ と同様の釣合条件が成立 しなければならない。この条件から， $\mathrm{AB}$ CD 間での コンクリート王縮応力の流れの向きが決定される。

C点のすぐ内側での釣合状態を図一 5 (b) に示す。 $\mathrm{C}$ 点内側では $p_{w h} \cdot \sigma_{w h}$ の大きさの环縮反力をせん断補強 筋から受ける。そこで，C点内側でのコンクリートの圧 縮主応力を $\sigma_{k}$ とすると, 鉛直方向の力の釣合いより, 次式を得る。

$$
p_{w h} \cdot \sigma_{w h} \cdot d x=\sigma_{k} \cdot d x \cdot \sin ^{2} \phi_{m}
$$

$\sin ^{2} \phi_{m}=1 /\left(1+\cot ^{2} \phi_{m}\right)$ を利用し，上式を $\sigma_{k}$ について 解くと, 次式を得る。

$$
\sigma_{k}=p_{w h} \cdot \sigma_{w h} \cdot\left(1+\cot ^{2} \phi_{m}\right)
$$

領域 $\mathrm{ABCD}$ では, トラス機構の角度が変化するため, コンクリートの主応力度が場所によって変化する。C点 すぐ内側での $\sigma_{k}$ が最大值となる。粗いハッチ, 細かい ハッチの領域でのコンクリートの主応力度も $\sigma_{k}$ を下回 る。したがって, $\sigma_{k} \leqq \nu \cdot \sigma_{B}$ の条件より，次式を得る。 ただしC点がヒンジ領域に属するので， $\nu \cdot \sigma_{B}$ はヒンジ 領域内の值を用いる。

$$
\cot \phi_{m} \leqq \sqrt{\frac{\nu \cdot \sigma_{B}}{p_{w h} \cdot \sigma_{w h}}-1}
$$

\section{(2) アーチ機構による負担せん断力}

アーチ機構は，基本的に非じん性部材と同じである。 ただしじん性部材の場合, アーチ機構でのコンクリート の圧縮応力度 $\sigma_{a}$ は, 有効強度 $\nu \cdot \sigma_{B}$ からトラス機構の最 大応力度 $\sigma_{k}$ を引いて, 次式で表される。

$$
\sigma_{a}=\nu \cdot \sigma_{B}-\sigma_{k}=(1-\beta) \cdot \nu \cdot \sigma_{B} \cdot
$$

ただし $\beta=\sigma_{k} /\left(\nu \cdot \sigma_{B}\right)$ とする。式 (12) より，

$$
\beta=\frac{p_{w h} \cdot \sigma_{w h} \cdot\left(1+\cot ^{2} \phi_{m}\right)}{\nu \cdot \sigma_{B}}
$$

となる。

図一2(b) において, BD の長さは $j_{t} \cdot \cot \phi_{m}$ である。 そこで, 非ヒンジ領域の長さが $j_{t} \cdot \cot \phi_{m}$ 以下の短い部 材では，図一6(a) の.ように中央部のハッ千領域が無く 


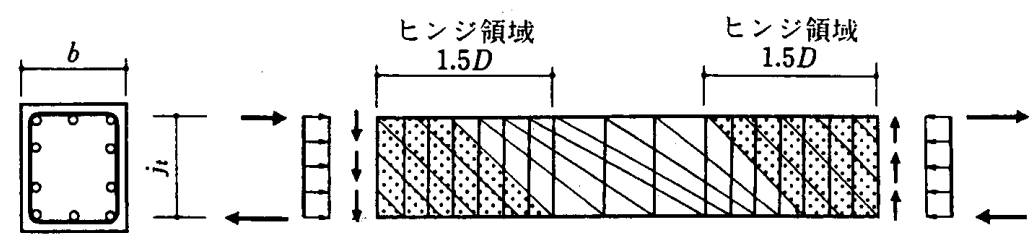

(a) やや短い両端ヒンジ部材

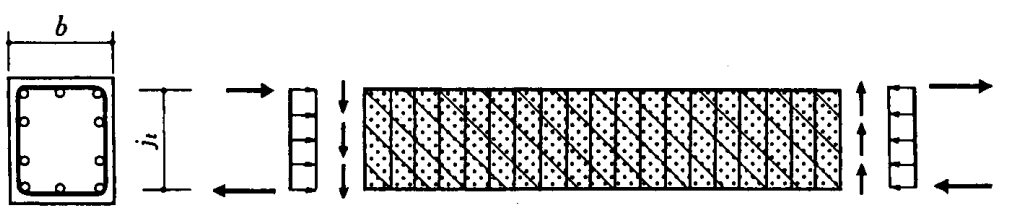

(b) 角度一様なトラス機構

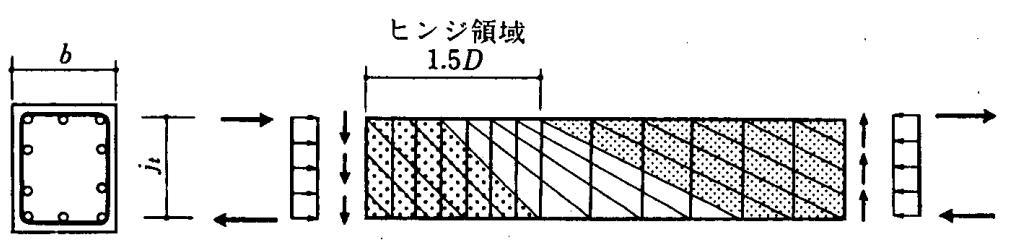

(c) 片端ヒンジの部材

図一6 その他のトラス機構

なることになる。このような部材では，図一-2(b) の部 材に比べて $\sigma_{k}$ と $\beta$ が小さくなる。したがって，図一6(a) の部材に本節の方法を適用すれば，ア一千機構の寄与を 正解よりも小さく評価することになり，安全側のせん断 強度が得られる。

ヒンジ領域内外でせん断補強筋量を一様 $\left(p_{w h}=p_{w m}\right)$ とした部材では, 式(8) より, $\cot \phi_{h}=\cot \phi_{m}$ となり, 図一6(b) のような一様卜ラス機構となる。この場合は, 式（12）により正確な $\sigma_{k}$ が得られるので, 本節の方法 で正しいせん断強度が得られる。

図一6(c) のような片側ヒンジの部材では，トラス機 構による応力状態が図一2(b) と全く同一となり，本節 の方法で正しいせん断強度が得られる。

\section{（3） せん断強度式}

通常のあばら筋，帯筋により補強した柱・梁のせん断 強度 $V_{u}$ は, トラス機構とアーチ機構の負担分の和とし て次式となる。すなわち

$$
\begin{aligned}
V_{u}= & b \cdot j_{t} \cdot p_{w m} \cdot \sigma_{w m} \cdot \cot \phi_{m} \\
& +b \cdot \frac{D}{2} \cdot(1-\beta) \cdot \nu \cdot \sigma_{B} \cdot \tan \theta
\end{aligned}
$$

となる(14)。ただしこの時点では $\sigma_{w h}$ と $\sigma_{w m}$ が未定であ ることに留意しておく。

式（16）は, $\beta$ に $\cot ^{2} \phi_{m}$ を含むため, $\cot \phi_{m}$ に関す る 2 次式であり, 次式の範囲内で $V_{u}$ が $\cot \phi_{m}$ ととも に増大する。

$$
\cot \phi_{m} \leqq \frac{p_{w m} \cdot \sigma_{w m} \cdot j_{t}}{p_{w h} \cdot \sigma_{w h} \cdot D \cdot \tan \theta}
$$

上式に式（8）を代入して次式を得る。

$$
\cot \phi_{h} \leqq \frac{j_{t}}{D \cdot \tan \theta}
$$

したがって塑性理論の下界定理により， $\cot \phi_{m}$ は, 式 (5)(13)（17）の範囲内 で最大の值を選んでよい。また, $\cot \phi_{h}$ は, 式 ( 4$)(10)(18)$ の範囲内で最大の 值を選んでよい。

なお，式（17）の右辺が 2 より小さく なるのは,

$p_{w h} \cdot \sigma_{w h}=p_{w m} \cdot \sigma_{w m}$ の場合では $\mathrm{L} / \mathrm{D}<$ 1.1 程度,

$p_{w h} \cdot \sigma_{w h}=2 p_{w m} \cdot \sigma_{w m}$ の場合では L/D< 2.5 程度の比較的短い部材のみである。 しかも式 (17)(18) の条件を無視して得 られる解は安全側である。したがって， 通常は式（17)(18) を無視しても良い。 最後に，未定量であった $\sigma_{w h}, \sigma_{w m}$ を 決定しなければならない。式（16）は， $\sigma_{w m}$ に関して単調に増加する注5)。した がって塑性理論の下界定理により無条件に $\sigma_{w m}=\sigma_{w y}$ と してよい。一方， $\sigma_{w h}$ に関しては, $\cot \phi_{m}$ と $\beta$ に $\sigma_{w h}$ を含むので，必ずしも単調増加にはならない。 $\sigma_{w h}$ は， 式（8）を介して $\cot \phi_{h}, \cot \phi_{m}$ と関連づけられた上 で決まる。

したがって，せん断強度 $V_{u}$ を求めるには, $\cot \phi_{m}$ と $\beta$ から未知数 $\sigma_{w h}$ を消去するのが有効である。まず, $\cot \phi_{m}$ に関しては，式（13）に式（8）を代入して次 式を得る。

$$
\cot ^{3} \phi_{m}+\cot \phi_{m} \leqq \frac{\nu \cdot \sigma_{B}}{p_{w m} \cdot \sigma_{w y}} \cot \phi_{h}
$$

また， $\sigma_{w h} \leqq \sigma_{w y}, \sigma_{w m}=\sigma_{w y}$ であるため，式（8）より，

$$
\cot \phi_{m} \leqq \frac{p_{w h}}{p_{w m}} \cot \phi_{h}
$$

でなければならない。 $\beta$ に関しては，式（15）に式（8） を代入して，次式を得る。

$$
\beta=\frac{p_{w m} \cdot \sigma_{w y} \cdot \cot \phi_{m} \cdot\left(1+\cot ^{2} \phi_{m}\right)}{\nu \cdot \sigma_{B} \cdot \cot \phi_{h}}
$$

結局, せん断補強筋量を非ヒンジ領域で減らした部材 のせん断強度 $V_{u}$ は, 次の手順で求められる。ただし, $p_{w m} \cdot \sigma_{w y}>\nu \cdot \sigma_{B} / 2$ の場合は, 以下の計算をするまでもな く, $V_{u}=b \cdot j_{t} \cdot \nu \cdot \sigma_{B} / 2$ となる。

(1) $\cot \phi_{h}$ は, $\cot \phi_{h} \leqq \lambda$ と式 (18) の範囲内で最大の 值を選ぶ。

(2) $\cot \phi_{m}$ は, $\cot \phi_{m} \leqq 2$ と式 (19)（20）の範囲内で 最大の值を選ぶ。ただしこの計算の結果, $\cot \phi_{h}>$ $\cot \phi_{m}$ 亡なる場合は, $\cot \phi_{h}=\cot \phi_{m}$ を式（19）に 代入して $\cot \phi_{h}=\cot \phi_{m}$ の值を計算し直す。

(3) 式 (21) により $\beta$ を計算する。 
(4) $\sigma_{w m}=\sigma_{w y}$ ，および上記の $\cot \phi_{m}$ よ $\beta$ を式 (16) に 代入して $V_{u}$ を求める。

\section{§4. せん断補強筋量とせん断強度との関係}

本節では, ヒンジ領域外のせん断補強筋量 $p_{w m} \cdot \sigma_{w y}$ とせん断強度 $V_{u}$ との関係を導く。また，そのときのヒ ンジ領域内のせん断補強筋の応力， $\sigma_{w h}$ について考える。 なお，本節では，L/D $\geqq 2.5$ 程度の部材を対象とするも のとし, 式 (17)(18) を無視する。L/D<2.5 の部材に 本項の結果を適用すれば，前述の理由により，正解より やや低めのせん断強度が得られる。

以下, $p_{w h} / p_{w m}$ の比率によって, 部材を 2 種類に分 類する。これは, $p_{w h} / p_{w m}$ の比率が大きい場合には, ヒンジ領域内のせん断補強筋の降伏が生じない（ $\sigma_{w h}<$ $\left.\sigma_{w y}\right)$ からである。さらに, ヒンジ領域外のせん断補強 筋量, $p_{w m} \cdot \sigma_{w y}$ によって, 4 種類の場合分けを行う。こ れは, ア一千作用の有無, せん断補強筋の降伏の有無に よる。

( 1 ) $\frac{p_{w h}}{p_{w m}}>\frac{2}{\lambda}$ の部材

(1 a) $\frac{p_{w m} \cdot \sigma_{w y}}{\nu \cdot \sigma_{B}}<\frac{\lambda}{10}$ の場合：

$\cot \phi_{h}=\lambda, \cot \phi_{m}=2, \beta<1$ 亡なるので,

$$
\begin{aligned}
V_{u}= & 2 \cdot b \cdot j_{t} \cdot p_{w m} \cdot \sigma_{w y} \\
& +b \cdot \frac{D}{2} \cdot(1-\beta) \cdot \nu \cdot \sigma_{B} \cdot \tan \theta
\end{aligned}
$$

となる。したがって, $p_{w m} \sigma_{w y}$ と $V_{u}$ との関係は, 図一7 (a) の直線 $\mathrm{AD}$ のようになる。図中のハッチはアーチ 作用の負担分を表す。直線の OD の傾きは 2 である。 また，式（8）より，

$$
p_{w h} \cdot \sigma_{w h}=\frac{2}{\lambda} \cdot p_{w m} \sigma_{w y}
$$

であるから， $p_{w h} \sigma_{w h}$ と $V_{u}$ との関係は, 図一 $7(\mathrm{~b})$ の直 線 $\mathrm{AD}^{\prime}$ のようになる。

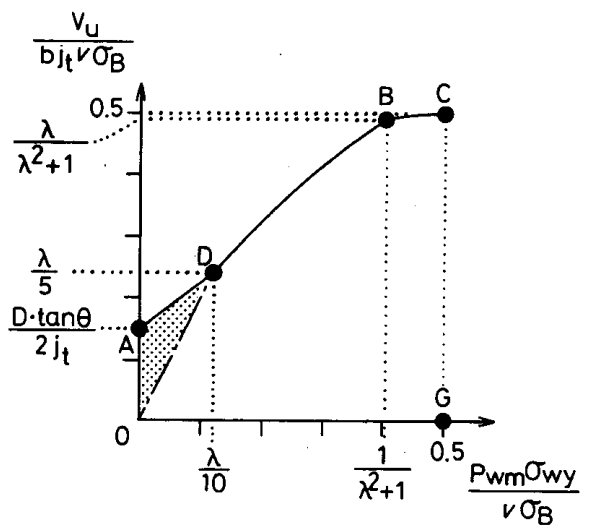

（a）ヒンジ領域外せん断補強筋量とせん断強度の関倸

図-7 $p_{w h} / p_{w m}>2 / \lambda$ の部材のせん断強度

\footnotetext{
( $p_{w h}, p_{w m}$ : ヒンジ領域内外のせん断補強筋比, $\lambda$ : 図一 3 による $\cot \phi$ の限)
}

(1 b) $\frac{\lambda}{10} \leqq \frac{p_{w m} \cdot \sigma_{w y}}{\nu \cdot \sigma_{B}}<\frac{1}{\lambda^{2}+1}$ の場合 :

$\cot \phi_{h}=\lambda, \beta=1$ となる。また, $\cot \phi_{m}$ は, 式 (19) より定まる。よって，

$$
V_{u}=b \cdot j_{t} \cdot p_{w m} \cdot \sigma_{w m} \cdot \cot \phi_{m}
$$

ただし, $\cot \phi_{m}=\sqrt[3]{q+r}+\sqrt[3]{q-r}$

$$
\begin{aligned}
& q=\frac{\nu \cdot \sigma_{B}}{2 \cdot p_{w m} \cdot \sigma_{w y}} \cdot \lambda \\
& r=\sqrt{q^{2}+(1 / 27)} .
\end{aligned}
$$

となる。また， $V_{u}=V_{t}=$ 式 $(6)$ より，

$$
p_{w h} \cdot \sigma_{w h}=\frac{V_{u}}{\lambda \cdot b \cdot j_{t}}
$$

となる。したがって, 図一7(a) の 3 次曲線 DB と図一 7 (b) の直線 D'B を得る。

(1 c) $\frac{1}{\lambda^{2}+1} \leqq \frac{p_{w m} \cdot \sigma_{w y}}{\nu \cdot \sigma_{B}}<\frac{1}{2}$ の場合：

式（19）にこの条件と $\cot \phi_{h}=\lambda$ を代入すると, $\cot \phi_{m}$ $\leqq \cot \phi_{h}$ となってしまう。したがって, 式 (10) より $\cot \phi_{h}=\cot \phi_{m}, \beta=1$ となる。よって,

$$
V_{u}=b \cdot j_{t} \cdot p_{w m} \cdot \sigma_{w m} \cdot \cot \phi_{m}
$$

ただし

$$
\cot \phi_{m} \leqq \sqrt{\frac{\nu \cdot \sigma_{B}}{p_{w m} \cdot \sigma_{w y}}-1}
$$

となる。また，

$$
p_{w h} \cdot \sigma_{w h}=p_{w m} \cdot \sigma_{w y}
$$

となる。したがって, 図一7(a)(b) の曲線 BC を得る。

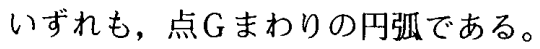

(1d) $\frac{p_{w m} \cdot \sigma_{w y}}{\nu \cdot \sigma_{B}} \geqq \frac{1}{2}$ の場合 :

無条件に

$$
V_{u}=b \cdot j_{t} \cdot \nu \cdot \sigma_{B} / 2
$$

となる。

( 2 ) $1 \leqq \frac{p_{w h}}{p_{w m}} \leqq \frac{2}{\lambda}$ の部材

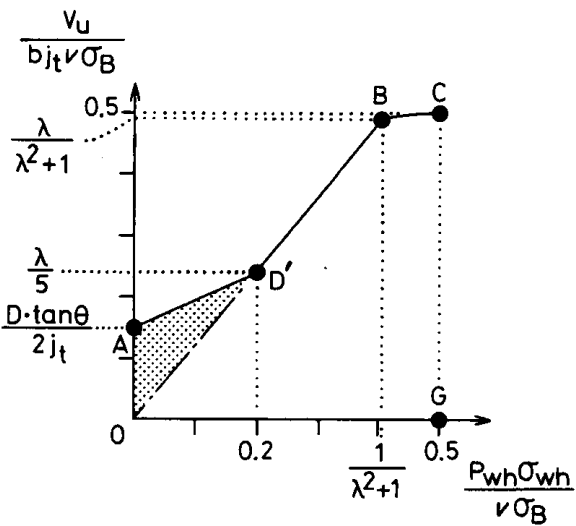

（b）ヒンジ領域内のせん断補強筋の応力 


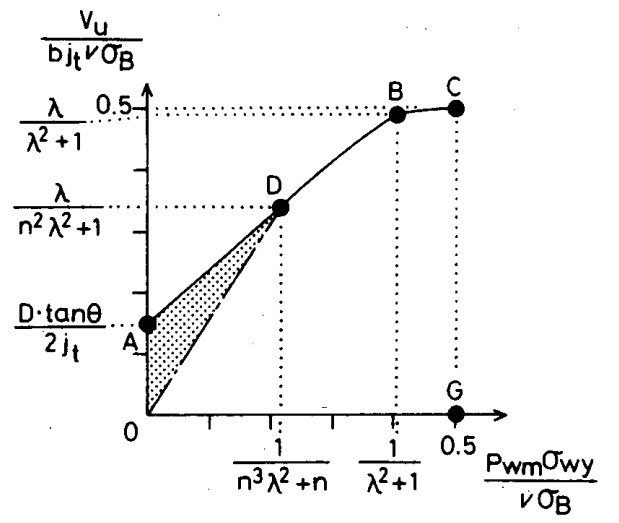

（a）ヒンジ領域外せん断補強筋量とせん断強度の関俰

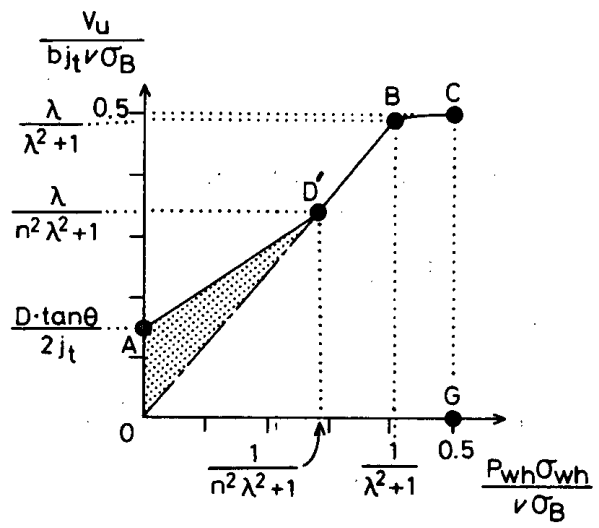

(b) ヒンジ領域内のせん断補強筋の応力

図一8 $\quad 1 \leqq p_{w h} / p_{w m} \leqq 2 / \lambda$ の部材のせん断強度 $\left(n=p_{w h} / p_{w m}\right)$

簡単のため, $n=p_{w h} / p_{w m}$ とおく。

(2 a) $\frac{p_{w m} \cdot \sigma_{w y}}{\nu \cdot \sigma_{B}}<\frac{1}{n^{3} \lambda^{2}+n}$ の場合：

$\cot \phi_{h}=\lambda, \beta<1$ となる。また, 式 (20) より, $\cot \phi_{m}$ $=n \cdot \lambda$ となる。そこで,

$$
\begin{aligned}
V_{u}= & n \cdot \lambda \cdot b \cdot j_{t} \cdot p_{w m} \cdot \sigma_{w y} \\
& +b \cdot \frac{D}{2} \cdot(1-\beta) \cdot \nu \cdot \sigma_{B} \cdot \tan \theta
\end{aligned}
$$

となる。したがって, 図一8(a) の直線 $\mathrm{AD}$ を得る。直

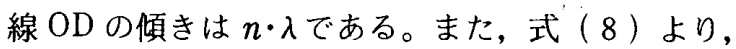

$$
p_{w h} \sigma_{w h}=\frac{n \cdot \lambda}{\lambda} \cdot p_{w m} \sigma_{w y}=p_{w h} \sigma_{w y}
$$

となる。つまり, $\sigma_{w h}=\sigma_{w y}$ となり，ヒンジ領域内のせ ん断補強筋は降伏する ${ }^{(116)}$ 。また, $p_{w h} \sigma_{w h}$ と $V_{u}$ との関 係は，図一8(b) の直線 $\mathrm{AD}^{\prime}$ のようになる。直線 $\mathrm{OD}^{\prime}$ の傾きは入である。

(2 b) ( $2 \mathrm{~d}) \quad \frac{p_{w m} \cdot \sigma_{w y}}{\nu \cdot \sigma_{B}} \geqq \frac{1}{n^{3} \lambda^{2}+n}$ の場合：

前述の (1 b) （1d) のケースと同じである。したがっ て, 図一8(a)(b) の $\mathrm{DBC}, \mathrm{D}^{\prime} \mathrm{BC}$ を得る。

上記の議論で $p_{w h}=p_{w m}$ とおけば，せん断補強筋量が 一様な部材のせん断強度が得られる。この場合, 図一8(a) (b) は, 図一 9 のようになる。つまり, 点 $\mathrm{D}, \mathrm{D}^{\prime}$ が右上

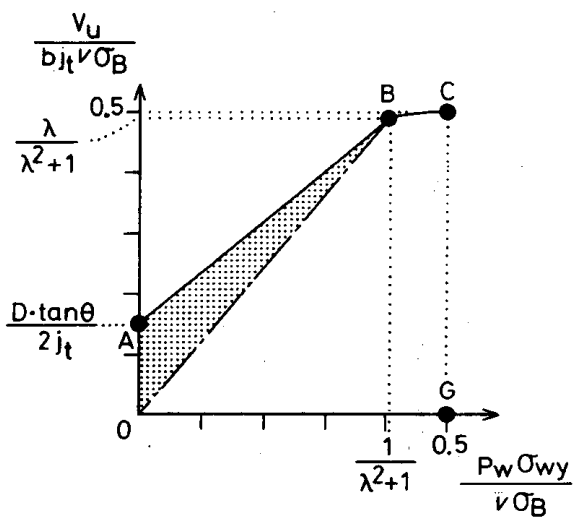

図一9 せん断補強筋量が一様な部材のせん断強度
に移動し, 点Bと一致する。

式 (17)（18）が関係するような短い部材の場合には, 図一7, 8 のA点が上に, D点と $\mathrm{D}^{\prime}$ 点が右上に移動し, $\mathrm{AD}$ と $\mathrm{DB}$ とが接する。図一 9 では，A点が上に移動し て, $\mathrm{AB} と \mathrm{BC}$ とが接する。

なお，保証ヒンジ回転角 $R_{p}=0$ の場合は $\lambda=2$ となる から，図-7(a)(b) と図一9は，図一10に示す非じん 性部材のせん断強度に一致する。また，図一8(a)(b) は， $1 \leqq p_{w h} / p_{w m} \leqq 2 / \lambda$ の部材（この場合， $\lambda=2$ より $p_{w h}=$ $p_{w m}$ の部材）に適用されるので，図一 9 と同じ扱いにな る。すなわち, 非じん性部材のせん断強度とじん性部材 のせん断強度とは連続している。

\section{§5. 必要せん断補強筋量}

作用せん断力 $V$ が与えられたときの必要せん断補強 筋量を考える。ただし,安全側の簡略化として式(17)(18) を無視する。

（1）せん断補強筋量をヒンジ領域内外で一様とする場 合。……図一9 の関係を解くことによって下記のよう に得られる。
(a) $\frac{V}{b \cdot j_{t} \cdot \nu \cdot \sigma_{B}}>\frac{1}{2}$ の場合 補強不可能。

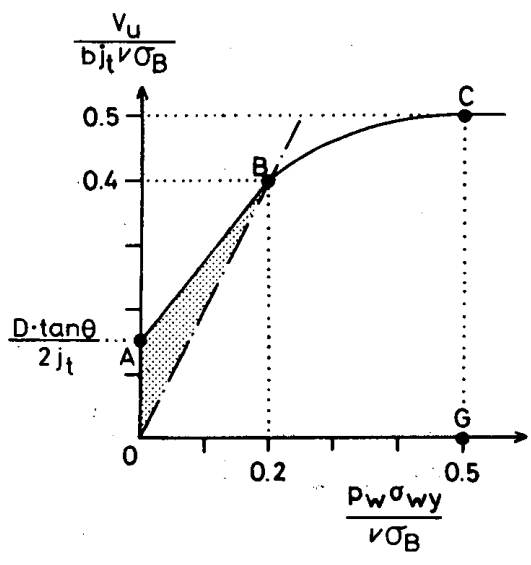

図一10 非じん性部材のせん断強度 
(b) $\frac{\lambda}{\lambda^{2}+1}<\frac{V}{b \cdot j_{t} \cdot \nu \cdot \sigma_{B}} \leqq \frac{1}{2}$ の場合

図一9 の BC 間。式 (29) に式 (30) 右辺を代入して次 式を得る。

$$
p_{w} \cdot \sigma_{w y}=\frac{\nu \cdot \sigma_{B}}{2}-\sqrt{\left(\frac{\nu \cdot \sigma_{B}}{2}\right)^{2}-\left(\frac{V}{b \cdot j_{t}}\right)^{2}}
$$

(c) $\frac{D \cdot \tan \theta}{2 \cdot j_{t}}<\frac{V}{b \cdot j_{t} \cdot \nu \cdot \sigma_{B}} \leqq \frac{\lambda}{\lambda^{2}+1}$ の場合

図一9 を得る。

$$
p_{w} \cdot \sigma_{w y}=\frac{V-\frac{b \cdot D \cdot \nu \cdot \sigma_{B} \cdot \tan \theta}{2}}{\lambda \cdot b \cdot j_{t}-\frac{\left(1+\lambda^{2}\right) \cdot b \cdot D \cdot \tan \theta}{2}} \cdots
$$

(d) $\frac{V}{b \cdot j_{t} \cdot \nu \cdot \sigma_{B}} \leqq \frac{D \cdot \tan \theta}{2 \cdot j_{t}}$ の場合

図一 9 の OA 間。アーチ機構のみで作用せん断力を負 担できるので，最少せん断補強筋量でよい。

（2）ヒンジ領域以外でのせん断補強筋量をできるだけ 減らそうとする場合。

図一9 之, 図一7(a) (b), 図一8 (b) (b) とを比較すると, 点 $\mathrm{A}$ とC はどの図でも同じ位置にある。したがって, せん断応力レベルが上記 (a)(d) の場合には, (1) と 全く同じ扱いとなる。

次に, 曲線 BC も, 図一7, 8, 9 で同一である。した がって，せん断応カレベルが上記（b) の場合には，ヒ ンジ領域内外でせん断補強筋量を一样とするのが合理的 である。

せん断応カレベルが上記 (c) の場合のみ，ヒンジ領 域内外でせん断補強筋量を変える価値が生じる。

$p_{w m} / p_{w h}$ の比率をできるだけ小さくする(つまり，ヒ ンジ領域以外でのせん断補強筋量をできるだけ減らそう とする)という立場で考えてみよう。この解は, 図一7(a)

(b) を逆に読むことによって，次のように得られる。

$$
\text { (c-1) } \frac{\lambda}{5}<\frac{V}{b \cdot j_{i} \cdot v \cdot \sigma_{B}} \leqq \frac{\lambda}{\lambda^{2}+1} \text { の場合 }
$$

図一7(a)(b) の DB，D'B 間である。 $V_{t}=V_{u}, \sigma_{w h}=$ $\sigma_{w y}$ であるから， $\cot \phi_{h}=\lambda$ を式（6）に代入して次式 を得る。

$$
p_{w h} \cdot \sigma_{w y}=\frac{V}{\lambda \cdot b \cdot j_{t}}
$$

また, $\cot \phi_{m}=$ 式“(13) 右辺を式（7）に代入して次 式を得る。

$$
p_{w m} \cdot \sigma_{w y}=\frac{V}{b \cdot j_{t} \cdot \sqrt{\frac{\nu \cdot \sigma_{B}}{p_{w h} \cdot \sigma_{w y}}-1}}
$$

(c-2) $\frac{D \cdot \tan \theta}{2 \cdot j_{t}}<\frac{V}{b \cdot j_{t} \cdot \nu \cdot \sigma_{B}} \leqq \frac{\lambda}{5}$ の場合

図-7(a)(b) の $\mathrm{AD}, \mathrm{AD}^{\prime}$ 間である。 $\cot \phi_{m}=2, \cot$ $\phi_{h}=\lambda$ をを式 (16) に代入して次式を得る。

$$
p_{w m} \cdot \sigma_{w y}=\frac{V-\frac{b \cdot D \cdot \nu \cdot \sigma_{B} \cdot \tan \theta}{2}}{2 \cdot b \cdot j_{t}-\frac{5 \cdot b \cdot D \cdot \tan \theta}{\lambda}}
$$

また，式（8）より次式を得る。

$$
p_{w h} \cdot \sigma_{w y}=\frac{2 \cdot p_{w m} \cdot \sigma_{w y}}{\lambda} \text {. }
$$

(c-1)(c-2) の場合とも，ヒンジ領域外で必要とされ る $p_{w m} \sigma_{w y}$ は， $p_{w}$ を一様とした場合の必要 $p_{w} \sigma_{w y} よ り$ も少なくて済む。しかし，ヒンジ領域内では逆になる。 したがって,ヒンジ領域外の長さが比較的短い部材では, $p_{w}$ を一様とする方が経済的である。

\section{§6. 実験結果との比較・検証}

本報告で仮定した $R_{\rho}$ と共に減少するため; 部材のせん断強度 $V_{u}$ もとン ジ回転角とともに図一11(a) のように低下することにな る。ただし， $R_{p}=0.05 \mathrm{rad}$ 以降は， $\nu$ と $\cot \phi_{h}$ が一定 なので $V_{u}$ も一定となる。一方, 曲げ強度 $V_{b u}$ はヒンジ 回転角の影響を全く受けないものと考える。せん断強度 $V_{u}$ と曲げ強度 $V_{b u}$ の交点を, 計算上のヒンジ回転能力 $R_{p u}$ と呼ぶ。ある寸法・配筋の部材の $R_{p u}$ を求めるには, $R_{p}$ を $0 \mathrm{rad}$ から $0.05 \mathrm{rad}$ まで少しずつ変化させて $V_{u}=$ $V_{b u}$ となるまで $V_{u}$ を計算し続ける必要がある。ただし， 実際の設計ではこのような繰返し計算は不要である。設 計では，骨組の弾塑性解析によって必要ヒンジ回転能力 が決まり（あるいは安全側の見積りとして指針案 4.4.5 の解説により梁で $R_{p}=1 / 100 \mathrm{rad}$, 柱で $R_{p}=1 / 67 \mathrm{rad}$ どとしてもよい), それに応じたっと $\cot \phi_{h}$ が自動的

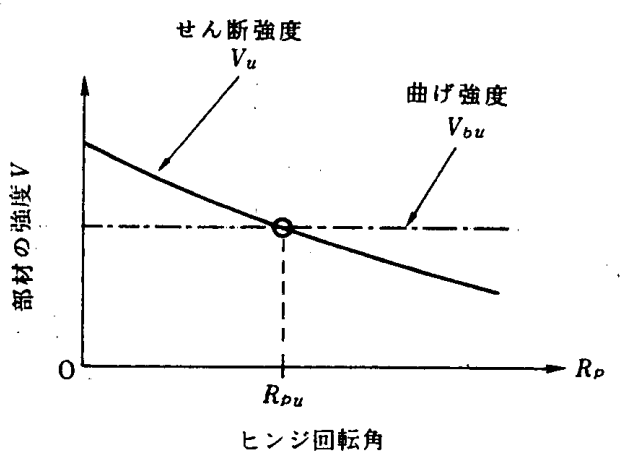

（a）計算上のヒンジ回転角

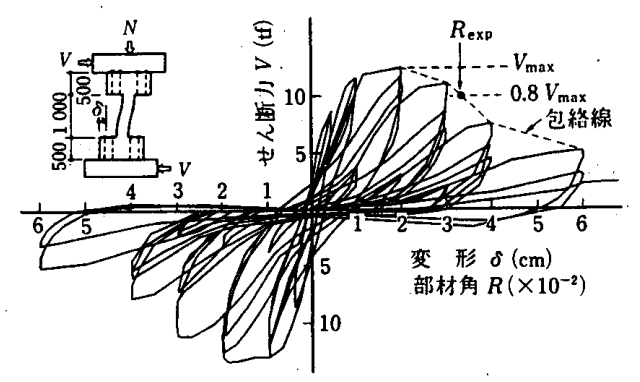

(b) 実験での定義

图一11変形能力の定義 


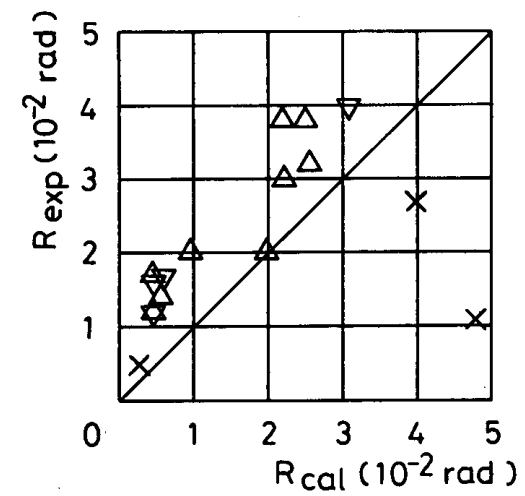

$\triangle: 0<\frac{\mathrm{N}}{\mathrm{bD} \sigma \mathrm{B}} \leqq \frac{1}{6}$

$\nabla: \frac{1}{6}<\frac{\mathrm{N}}{\mathrm{bD} \sigma \mathrm{B}} \leqq \frac{1}{3} \quad x: \frac{\mathrm{N}}{\mathrm{bD} \sigma \mathrm{B}}>\frac{1}{3}$

図一12 変形能力の検証

に決まるからである。

吉岡 ${ }^{12)}$ が選定した実験値のうち，付着破壊しなかつ た実験データを用いて変形能力に関する精度を検討す る。いずれの試験体もせん断補強筋量は部材内で一様で ある。変形能力の実験值 $R_{\exp }$ は, 図一11(b) のように, 荷重変形包絡線が最大荷重 $V_{\max }$ の $80 \%$ になったとき の部材角で定義した。計算值 $R_{\text {cal }}$ は, 塑性ヒンジの回 転能力 $R_{p u}$ と降伏時の部材角 $R_{y}$ (菅野 ${ }^{13)}$ の式で計算) の和とした。計算値 $R_{\text {cal }}$ と実験值 $R_{\exp }$ の関係を図-12 に示す。軸力の大きい試験体（×印）で危険側になるも のが 2 体あるが，これは $N /\left(b D \sigma_{\mathrm{B}}\right)=0.44$ および 0.58 で軸力比が極めて高く，曲げ圧縮破壊であった。また， 指針案第 9 章の特別ヒンジ配筋詳細規定を満足していな い。これ以外の試験体はすべて実験值が計算值を上回っ た。すなわち安全側の結果となった。

しかし，上記の検証には次のような問題がある。これ らについては, 今後の研究の発展に期待したい。

\section{（1）変形能力の定義方法}

上記の検証では，荷重変形の包絡線のみに着目して， 繰返し回数などの条件は無視した。しかし, 繰返し回数 が荷重変形関係の包絡線に影響を与えるという報告もあ る。また，包絡線の低下がなくても，繰返し耐力やエネ ルギー吸収能力の低下が生じれば，建物全体のじん性に 影響が生じる。したがって, 変形能力の定義を再検討し, 検証方法を確立する必要がある。

（2）検証例の不足（パラメトリックな分析）

曲げ降伏前のせん断強度については，文献 7）にて, せん断補強筋量, コンクリート強度, 軸力など, 種々の パラメーターが実験との適合性に与える影響が検討され ている。その結果, 非じん性部材に関しては, 設計法の 問題点と適用限界も多少明らかになったといえる(特に, せん断補強筋量が少ない柱での軸力の効果)。しかし, 本報告の検証では，パラメトリックな分析とはなってい
ないため, じん性部材の設計法の問題点と適用限界が不 明確である。

（3）部材中央でせん断補強筋を減らした部材への適用 性

本報告の検証では，部材全域でせん断補強筋が一様な 場合のみを対象としている。部材中央でせん断補強筋を 減らした部材への適用性を明らかにする必要がある。そ の場合，ヒンジ領域の幅を一律に $1.5 D$ としてよいか どうかも同時に検討すべきであろう。

\section{§7. 指針案のせん断設計式との関係}

指針案 ${ }^{(6)}$ では，ヒンジ領域内外のせん断強度が独立に 与えられるものとしている。これは，以下に示すように， 本報告の設計法を安全側に簡略化したものであると言え る。ただし，本節でも，式 (17)(18) が関係しない程度 の，通常の長さの部材を考える。

指針案では, $\cot \phi_{m}$ を次式のうちの最小値とする。

$$
\begin{aligned}
\cot \phi_{m} & =2 \ldots \ldots \ldots \ldots \ldots \ldots \\
\cot \phi_{m} & =\sqrt{\frac{\nu \cdot \sigma_{B}}{p_{w h} \cdot \sigma_{w y}}-1}
\end{aligned}
$$

$\cot \phi_{h}$ は，次式のうちの最小值とする。

$$
\begin{aligned}
& \cot \phi_{h}=\lambda \\
& \cot \phi_{h}=\text { 式 (13') 右辺 }
\end{aligned}
$$

$\beta$ は, 次式で計算する。

$$
\beta=\frac{p_{w h} \cdot \sigma_{w y} \cdot\left(1+\cot ^{2} \phi_{m}\right)}{\nu \cdot \sigma_{B}}
$$

式 $\left(13^{\prime}\right)\left(15^{\prime}\right)$ は，式 (13)(15) で， $\sigma_{w h}=\sigma_{w y}$ と置き換 えて得られる。その結果, ヒンジ領域内のせん断強度は, 図一7(b) の横軸を $\sigma_{w h} \rightarrow \sigma_{w y}$ と置き換えることによっ て, 図一13(a) のように与えられる。また, ヒンジ領域 外のせん断強度は, 図一13(b) の上うに与えられる。 図-13(b) の $\mathrm{AD}$ 間では, $\cot \phi_{m}=2$ であり, 直線 $\mathrm{OD}$ の傾きは 2 である。DE間では, $\cot \phi_{m}=$ 式 $\left(13^{\prime}\right)$ であ り， DE は点 $\mathrm{H}$ を中心とする円弧である。 $\mathrm{EC}$ 間では， $\cot \phi_{m}=1$ であり，直線 EC の傾きは 1 である。

図-13(a) (b) の点 $D^{\prime}$ と点 D の高さが一致しないの は式（8）の釣合い条件を無視したためである。 $n>$ $2 / \lambda$ の部材では, 点 $D^{\prime} よ り$ 点 $\mathrm{D}$ の方が低くなるので, 図一13(b) が部材のせん断強度を代表する。 $n \leqq 2 / \lambda の$ 部材では, 点 D'より点 D の方が高いので, 図一13(a)(b) を組み合わせて得られる図一14 が部材のせん断強度を 表す。図一14のうち,ヒンジ領域内のせん断強度に支 配されるのは，折れ線 ADF である。ADF 間では cot

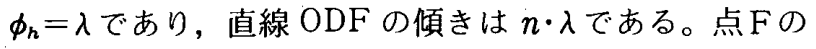
座標は, 図一8(a) の点 Dと同じである。

図一13(b) は図一7(a) よりも，図一14は図一8(a)・ 図一9よりも低いせん断強度を与える。したがって, 指 針案は, 本報告の設計法を安全側に簡略化したものであ 


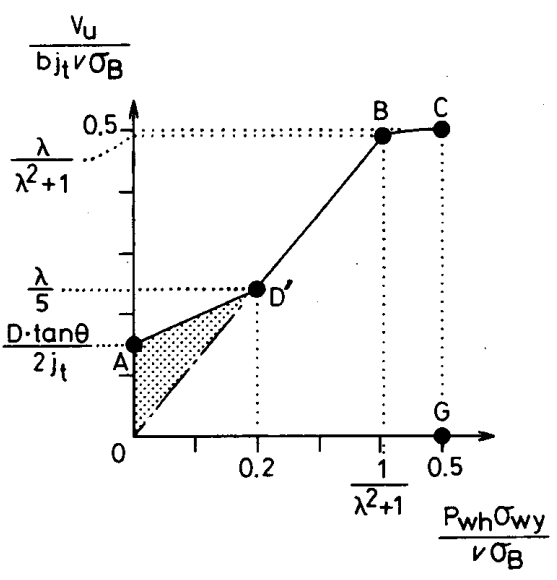

(a) ヒンジ領域内

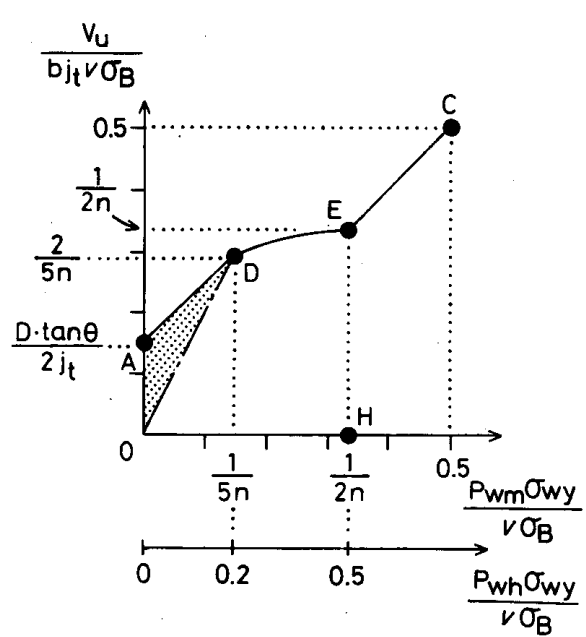

(b) ヒンジ領域外 $\left(n=p_{w n} / p_{w m}\right)$

図一13 指針案によるせん断強度

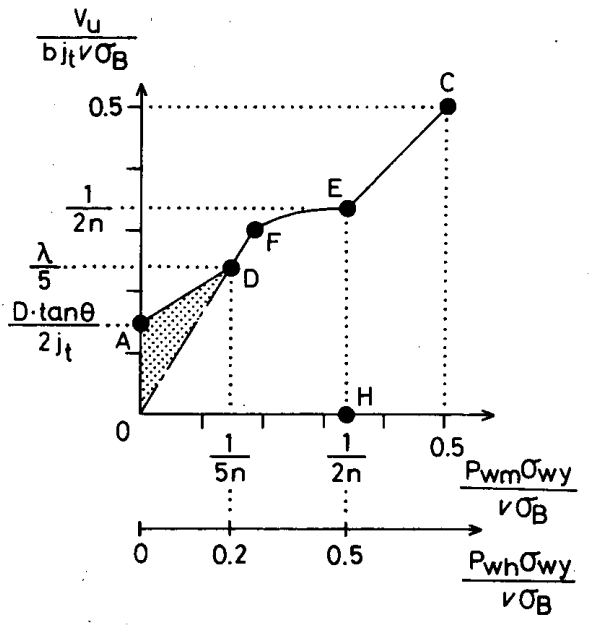

図一14指針案によるせん断強度，( $p_{w h} / p_{w m} \leqq 2 / \lambda$ の部材 $)$

ると言える。ただし，指針案以外の方法でも簡略化は可 能汭7であり，検討の余地がある。

\section{§8. 結 論}

（1）塑性ヒンジ領域内でのコンクリートの有効強度と トラス機構の角度を, ヒンジ回転角に応じて図一1, 図 一3のように制限することにより, 曲げ降伏後の部材の せん断破壊を防ぐための設計条件を導くことができる。 （2）ヒンジ領域内外でせん断補強筋量が異なる部材の 場合, せん断補強筋量とせん断強度の関係は, 図一7(a) • 図一8(a) のように表される。

（3）せん断補強筋量が一様な部材の場合, せん断補強 筋量とせん断強度の関係は，図一 9 のように表される。 (4) 指針案 ${ }^{(6)}$ に示されたじん性部材のせん断強度式 は, 図一7(a), 図一8(a), 図一9を安全側に簡略化した ものである。

（5）今後, 検証例を積み重ねて, 本設計法（および指 針案(6)の設計法) の適用限界を明らかにする必要がある。

\section{謝 辞}

名古屋工業大学教授・工博・大岸佐吉先生には，全般 的な御指導を得た。本研究の発端は文献 14）にあり, その際, 東京大学教授・工博・青山博之先生, 同助教授・ 工博 - 小谷俊介先生はじめ関連の先生方には有益な助言 を賜った。さらに本研究の内容は, 日本建築学会・鉄筋 コンクリート構造耐震設計小委員会に設けられたせん断 $W G$ で討議された。同 WG 主査・京都大学助教授・工 博 - 渡辺史夫先生はじめ, 委員の先生方には有益な意見 を賜った。厚く御礼申し上げます。

\section{参考文献}

1) Nielsen, M. P. : Limit Analysis and Concrete Plasticity, Prentice Hall, p. 420, 1984

2) Thurlimann, B. : Plastic Analysis of Reinforced Concrete Beams, Introductory Report of IABSE Colloquium, Kopenhagen, Plasticity in Reinforced Concrete, pp. 71-90, 1979

3）称原良一, 加藤 勉：鉄筋コンクリート部材の耐力（圧 力場理論の適用), 日本建築学会大会学術講演梗概集, pp. $1731-1732,1978$

4）南 宏一：せん断を受ける鉄筋コンクリート部材の極限 解析について, RC 構造のせん断問題に対する解析的研 究に関するコロキウム, 日本コンクリート工学協会, pp. 1-16, 1982

5) M.P. Collins and D. Mitchell : A rarional approach to shear design - The 1984 Canadian code provisions, Journal of the American Concrete Institute, Vol.83, No. 6 , pp. 925-933, 1986

6) 日本建築学会：鉄筋コンクリート造建物の終局強度型耐 震設計指針 (案) ・解説, 1988.10

7）市之瀬敏勝, 大岸佐吉, 數内智治, 青山博之, 渡辺史夫 : 鉄筋コンクリート梁柱部材のせん断設計法, 日本建築 学会東海支部研究報告集, pp. 137-148, 1988.3

8）市之瀬敏勝, 大岸佐吉, 青山博之, 渡辺史夫 : 鉄筋コン クリート梁柱部材のせん断設計法, コンクリート工学年 次論文報告集, Vol. 10, No. 3, pp. 657-662, 1988 
9) Vecchio, F. J. and Collins, M. P. : The Modified Com: pression Field Theory for Reinforced Concrete Elements Subjected to Shear, ACI Journal, Vol.83, pp. 219-231, March-April, 1986

10）白井伸明, 松井洋司, 佐藤稔雄：ひびわれを含むコンク リートの圧縮劣化特性, コンクリート工学年次論文報告 集, Vol.11, No.2, pp.317-322, 1989

11）大久保雅章, 濱田 聡, 野口 博：地震時のひび割れコ ンクリートの圧縮特性の劣化に関する基礎実験, JCI コ ロキウム「 「RC 構造のせん断設計法に関する解析的研究」 論文集，pp.17-22，1989.10

12）吉岡研三：「柱選定試験体」選定理由および実験デー夕の 概要, $\mathrm{RC}$ 構造のせん断問題に対する解析的研究に関す るコロキウム, 日本コンクリート工学協会, pp. 9-20, 1983

13）菅野俊介：鉄筋コンクリート構造物の塑性剛性に関する 研究 (その 3$)$ ，日本建築学会関東支部研究報告集，1968

14）青山博之：鞋性に依存する鉄筋コンクリート造建築物の 耐震設計法の開発に関する研究, 昭和 60 年度科学研究費 補助金 (総合研究 A) 研究成果報告書; 1986.3

15) Walraven, J.C. : Fundamental Analysis of Aggregate Interlock, J. of the Structural Devision, ASCE, Vol.107, No.ST11, pp. 2245-2270, Nov. 1981

注

1）実際のところ, 式 ( 3 ), 図一1 の仮定は，§6で実験結 果との適合性が良くなるように，経験的に定めた。

2）分布荷重の存在する梁の場合は, 断面 $\mathrm{AB}$ と $\mathrm{CD}$ とでせ ん断力が異なるので，必ずしも式（8）が成立するとは 限らない。しかし，せん断力の差は，図一2(b) の AC 間 で加わる分布荷重のみであり, 通常は無視できる程度で あろう。

3）説明の簡略化のため, 「 $p_{w n} \geqq p_{w n}$.の条件から, $p_{w h} \cdot \sigma_{w h} \geqq$ $p_{u m} \cdot \sigma_{w m}$ となる」と述べたが, 厳密にはこれは正しくない。 むしろこの段階では, $「 p_{w h} \cdot \sigma_{w h} \geqq p_{w m}: \sigma_{w m}$ を仮定して議 論を進める」と言う方が正確である。この仮定の正当性は，
次のように証明される。まず， $p_{w h}>p_{w m}$ の場合に $p_{w h}$. $\sigma_{w h}<p_{w m} \cdot \sigma_{w m}$ を仮定すると，図一7，8で得られたせん 断強度よりも低いせん断強度が得られる。したがって, 下界定理により， $p_{w h}>p_{w m}$ の場合に $p_{w h} \cdot \sigma_{w h} \geqq p_{w m} \cdot \sigma_{w m}$ を仮定するのは正しい。次に， $p_{w h}=p_{w m}$ の場合に $p_{w h} \cdot \sigma_{w h} \neq p_{w m} \cdot \sigma_{w m}$ を仮定すると，図一 9 で得られたせん 断強度よりも低いせん断強度が得られる。したがって, $p_{w h}=p_{w m}$ の場合に $p_{w h} \cdot \sigma_{w h}=p_{w m} \cdot \sigma_{w m}$ を仮定するのは正 しい。

4）式（16）のせん断強度 $V_{u}$ は，ヒンジ領域外でのせん断 補強筋量， $p_{w m}$ により表現されているが，これは，ヒン ジ領域外でのせん断強度を単に表しているわけではない。 式(6)(7)の $V_{t}$ が等しいことからわかるように, 式(16) は, ヒンジを持つ部材全体としてのせん断強度を表して いる。部材がどの領域でせん断破壊するかは，条件によ り異なる。図一2(b) のように，傾きの変化するトラス作 用が生じる部材では, 図一 $2(\mathrm{~b})$ の C 点近傍でのコンクリー トの圧縮破壊が先行するので，見かけ上，ヒンジ領域外 でせん断破壊が生じる。図一6(b) のように，傾きの一様 なトラス作用が生じる部材では，ヒンジ領域内でのレが 小さいことから，せん断破壊はヒンジ領域内で生じる。

5）ただし，§4の結果からわかるように, 正確には, 「 $p_{u m}$. $\sigma_{w y}>\nu \cdot \sigma_{B} / 2$ の範囲内で……」と言うべきである。

6) 逆に言えば,これ以外のケースでは, ヒンジ領域内のせ ん断補強筋は降伏しない。しかしこれは：図一2のよう なトラス機構を仮定したからであって, 実際の部材では, 曲げせん断ひび割れの拡大などにより、これ以外のケー スであってもヒンジ領域内のせん断補強筋の降伏は有り 得る。

7）例えば, 図一8の ADBC を折れ線表示するなど。この場 合，せん断補強筋量を 1 次式で計算できる利点がある。 その他, 式 (13)(15) で， $\sigma_{w h}=\sigma_{w y}$ と仮定するなどの方 法も考えられる。

(1990 年 2 月 10 日原稿受理, 1990 年 7 月 4 日採用决定) 